\title{
Degradation of 2-methylaniline in Rhodococcus rhodochrous: cloning and expression of two clustered catechol 2,3-dioxygenase genes from strain CTM
}

\author{
Angelika Schreiner, Klaus Fuchs, $†$ Friedrich LotTsPeich, $\ddagger$ Harald Poth $§$ and \\ FRANZ LiNGENS*
}

Institut für Mikrobiologie, Universität Hohenheim, Garbenstaße 30, D-7000 Stuttgart 70, FRG

(Received 31 December 1990; revised 2 April 1991; accepted 13 May 1991)

\begin{abstract}
Rhodococcus rhodochrous strain CTM degrades 2-methylaniline mainly via the meta-cleavage pathway. Conversion of the metabolite 3-methylcatechol was catalysed by an $M_{\mathrm{r}} 156000$ catechol 2,3-dioxygenase (C230I) comprising four identical subunits of $M_{\mathrm{r}} \mathbf{3 9 0 0 0}$. The corresponding gene was detected by using an oligonucleotide as a gene probe. This oligonucleotide was synthesized on the basis of a partial amino acid sequence obtained from the purified enzyme from $R$. rhodochrous. The structural gene of $\mathrm{C} 230 \mathrm{I}$ was located on a $3.5 \mathrm{~kb} \mathrm{Bg} / \mathrm{II}$ restriction fragment of plasmid pTC1. On the same restriction fragment the gene for a second catechol 2,3-dioxygenase, designated C23OII, was found. This gene coded for the synthesis of the $M_{\mathrm{r}} \mathbf{4 0 0 0 0}$ polypeptide of the $M_{\mathrm{r}} 158000$ tetrameric C23OII. More precise mapping of the structural genes showed that the C23OI gene was located on a $1.2 \mathrm{~kb} \mathrm{Bg} / \mathrm{II}-\mathrm{SmaI}$ fragment and the C23OII gene on the adjacent $1.15 \mathrm{~kb}$ SmaI fragment. Comprehensive substrate range analysis showed that $\mathrm{C} 230 \mathrm{II}$ accepted all the substrates that $\mathrm{C23OI}$ did, but additionally cleaved 2,3-dihydroxybiphenyl and catechols derived from phenylcarboxylic acids. C23OI exhibited highest activity towards methylcatechols, whereas C23OII cleaved unsubstituted catechol preferentially.
\end{abstract}

\section{Introduction}

In the preceding paper (Fuchs et al., 1991) we described the catabolism of 2-methylaniline by Rhodococcus rhodochrous wild-type strain CTM and a spontaneous mutant CTM2. Strain CTM metabolized 2-methylaniline chiefly via the meta-cleavage pathway. In strain CTM2, however, cleavage of 3-methylcatechol was exclusively intradiol (ortho-cleavage). Enzyme assays on crude extracts showed the presence of catechol 2,3dioxygenase as an inducible enzyme in $R$. rhodochrous strain CTM, but not in strain CTM2.

The only genetic data on the metabolism of methylanilines that have been published previously (McClure $\&$ Venables, 1987) concerned a conjugative plasmid pTDN1 in Pseudomonas strain UCC2. This plasmid harboured the degradative genes for the catabolism of

† Present address: Kronwald Separationstechnik, D-6920 Sinsheim, FRG.

$\ddagger$ Present address: Genzentrum, D-8033 Martinsried, Am Klopferspitz, FRG.

$\S$ Present address: GBF, Microbiology Division, D-3300 Braunschweig, FRG.

Abbreviation: C230, catechol 2,3-dioxygenase. aniline and 3- and 4-methylaniline. The $\mathrm{C} 23 \mathrm{O}$ structural gene was located on a $1.9 \mathrm{~kb}$ HindIII restriction fragment (Saint et al., 1990) and coded for an enzyme which preferentially cleaved methylcatechols (Wallis \& Chapman, 1990).

In this paper we describe the cloning of two $\mathrm{C} 23 \mathrm{O}$ genes and some properties of the corresponding enzymes from $R$. rhodochrous CTM.

\section{Methods}

Bacterial strains and culture conditions. Isolation and culture of $R$. rhodochrous strains CTM and CTM2 are described in the preceding paper (Fuchs et al., 1991). For enzyme purification, cells of $R$. rhodochrous CTM were cultivated in a 5001 fermenter on mineral medium supplemented with sorbitol. After induction with 2-methylaniline $(1 \mathrm{~mm})$, bacteria were harvested when the culture fluid reached its absorption maximum at $387 \mathrm{~nm}$ due to the formation of 2-hydroxy6-oxoheptadienoic acid. For plasmid DNA preparations the strain was cultivated in LB-medium (Maniatis et al., 1989) with $10 \mathrm{mM}$-DLthreonine. Recombinant $E$. coli strains were grown in Oxoid antibiotic medium no. 3 (AM3) containing $100 \mu \mathrm{g}$ ampicillin $\mathrm{ml}^{-1}$. Details of strains used in this work are shown in Table 1. 
Table 1. Bacterial strains and plasmids

\begin{tabular}{|c|c|c|}
\hline Strain & $\begin{array}{l}\text { Plasmids and relevant } \\
\text { phenotypes/genotypes }\end{array}$ & Source \\
\hline \multicolumn{3}{|c|}{ R. rhodochrous } \\
\hline $\begin{array}{l}\text { CTM } \\
\text { CTM2 }\end{array}$ & $\begin{array}{l}\text { pTCl }\left(\mathrm{C}_{23 \mathrm{OI}^{+}} \mathrm{C}^{2} 3 \mathrm{OII}^{+}\right), \text {pTC2 (cryptic) } \\
\text { pTC1-2 }\left(\mathrm{C}^{2} 3 \mathrm{OI}^{-} \mathrm{C} 23 \mathrm{OII}^{-}\right), \text {pTC2 }\end{array}$ & This study \\
\hline \multicolumn{3}{|c|}{ E. coli } \\
\hline TG1 & $\Delta($ lac-pro $)$ thi $\sup E\left(r_{\overline{\mathrm{K}}} m_{\overline{\mathrm{K}}}\right)$ & \\
\hline DH 1 & $h s d R I 7\left(r_{\mathrm{K}}^{-} m_{\mathrm{K}}^{+}\right)$ & Maniatis et al. (1989) \\
\hline $\mathrm{DHI}$ & pMVS301 (Ap Thio $\left.^{r}\right)$ & Vogt Singer \& Finnerty (1988) \\
\hline DHI & pUC18/pUC19 (AprlacZ) & Vieira \& Messing (1982) \\
\hline DH1 & pJOE875 $\left(\mathrm{Ap}^{r} \mathrm{Thio}^{\mathrm{r}} \mathrm{Mel}^{+}\right)$ & J. Altenbuchner Stuttgart, FRG \\
\hline $\mathrm{DH} 1$ & pASI360 $\left(\mathrm{Ap}^{r} \mathrm{C} 23 \mathrm{OI}^{+} \mathrm{C}_{23} \mathrm{OII}^{+}\right)$ & \\
\hline DH1 & pAS1361 $\left(\mathrm{Ap}^{r} \mathrm{C}_{23} \mathrm{OI}^{+} \mathrm{C} 23 \mathrm{OII}^{+}\right)$ & \\
\hline TG1 & pAS2600 $\left(\mathrm{Ap}^{\mathrm{r}} \mathrm{C} 23 \mathrm{OI}^{-} \mathrm{C}^{2} 3 \mathrm{OII}^{+}\right)$ & \\
\hline DH1 & pAS1 $1700\left(\mathrm{Ap}^{\mathrm{r}} \mathrm{C} 23 \mathrm{OI}^{-} \mathrm{C} 23 \mathrm{OII}^{+}\right)$ & This study \\
\hline DHI & pAS1200 ( $\left.\mathrm{Ap}^{\mathrm{r}} \mathrm{C} 23 \mathrm{OI}^{-} \mathrm{C}^{2} 3 \mathrm{OII}^{-}\right)$ & \\
\hline DH1 & pAS1150 (Ap $\left.{ }^{r} \mathrm{C} 23 \mathrm{OI}^{-} \mathrm{C} 23 \mathrm{OII}^{+}\right)$ & \\
\hline TG1 & pAS2400 $\left(\mathrm{Ap}^{r} \mathrm{C} 23 \mathrm{OI}^{+} \mathrm{C} 23 \mathrm{OII}^{+}\right)$ & \\
\hline
\end{tabular}

Detection of $\mathrm{C} 23 \mathrm{O}$ activity.

(i) In whole cells. E.coli clones expressing $\mathrm{C} 23 \mathrm{OI}$ were detected by the catechol spray test (Worsey et al., 1978) using ferrous ammonium sulphate (10 mM) followed by 3-methylcatechol (5 mM) in buffer A (20 mm-potassium phosphate, $\mathrm{pH} 7.5$ ). For detection of $\mathrm{C} 23 \mathrm{OII}$ activity, a solution of $5 \mathrm{~mm}$-2,3-dihydroxybiphenyl, dissolved in acetone, was sprayed on the colonies.

(ii) In crude extracts. Samples of crude extracts (0.5-2 mg protein) were pre-incubated with $0.2 \mathrm{~mm}$ (final concentration) 3-methylcatechol. The amount of 2-hydroxy-6-oxoheptadienoic acid formed was estimated as described by Rast et al. (1980). The same extinction coefficient at $390 \mathrm{~nm}$ was used to determine meta-cleavage products from chloromethylcatechols. On polyacrylamide gels, protein bands carrying $\mathrm{C} 23 \mathrm{O}$ activity were detected by an activity-staining procedure according to Schmitt et al. (1984).

C23OII activity was assayed using biphenyl-2,3-diol as substrate. The reaction mixture (final vol. $1 \mathrm{ml}$ ) contained $3-5 \mathrm{mg}$ protein. Preincubation with $\mathrm{Fe}^{2+}$ was omitted and the reaction was started by addition of $0.5 \mathrm{~mm}$ (final concentration) 2,3-dihydroxybiphenyl dissolved in acetone. The formation of 2-hydroxy-6-oxo-6-phenylhexadienoic acid was followed at the absorption maximum of $432 \mathrm{~nm}$, and quantified using the extinction coefficient described by Catelani \& Colombi (1974).

Purification of $C 23 O$ from $R$. rhodochrous. All purification steps were done at $4{ }^{\circ} \mathrm{C}$ using buffer $\mathrm{A}$. Cells were harvested at the end of the exponential growth phase. Disruption of the cells was achieved by three passages through a French press at 20000 p.s.i. (about $138 \mathrm{MPa}$ ). After centrifugation $(48000 \mathrm{~g})$ the supernatant was used as crude extract. The cell-free extract was then applied onto a DEAE cellulose column $(15 \times 5.5 \mathrm{~cm})$, previously equilibrated with buffer A. Enzyme was eluted with a linear gradient of $0-600 \mathrm{mM}-\mathrm{KCl}$ in buffer $\mathrm{A}$. Fractions containing active enzyme were combined and passed through a Superose-12 gel filtration column (type HR 10/30, Pharmacia/LKB) with a flow rate of $0.3 \mathrm{ml} \mathrm{min}^{-1}$. Fractions with $\mathrm{C} 23 \mathrm{O}$ activity were again combined and brought to $1.7 \mathrm{M}-\left(\mathrm{NH}_{4}\right)_{2} \mathrm{SO}_{4}$. Further purification was obtained by hydrophobic interaction chromatography on phenyl-Superose (MonoP, type HR 5/5). The enzyme was eluted with a linear $\left(\mathrm{NH}_{4}\right)_{2} \mathrm{SO}_{4}$ gradient $(1 \cdot 7-0 \mathrm{M})$.
Molecular mass determination. Molecular masses of subunits were determined using SDS-PAGE according to Laemmli (1970). Native molecular masses were determined by gel filtration using buffer $A$. The flow rate was $0 \cdot 4 \mathrm{ml} \mathrm{min}^{-1}$.

Isoelectric focusing. The isoelectric point of the purified enzyme was determined on Ampholine-PAGE plates (Pharmacia/LKB) with a $\mathrm{pH}$ range of $3.5-9.3$ at $10^{\circ} \mathrm{C}$ on a horizontal LKB 2117 Multiphor apparatus.

pH optimum. C23Ol activity was assayed in Britton-Robinson buffer (Britton \& Robinson, 1931) at different pH values with 3-methylcatechol as substrate.

Iron content. The iron content of purified C23OI was determined by energy dispersive $\mathrm{X}$-ray fluorescence spectroscopy in relation to an internal iron standard.

Influence of metal ions and other agents. Samples $(160 \mu \mathrm{g})$ of purified $\mathrm{C} 23 \mathrm{OI}$ were pre-incubated in buffer $\mathrm{A}$ for $10 \mathrm{~min}$ at $25^{\circ} \mathrm{C}$ with various amounts (up to $3 \mathrm{mM}$ ) of different metal ions, 2,2'-bipyridyl (1.36.4 mM), 1,10-phenanthroline (11 mM), ascorbate (up to $1 \mathrm{~mm}$ in $0.1 \mathrm{~mm}$ steps) and $0.03 \%(\mathrm{v} / \mathrm{v}) \mathrm{H}_{2} \mathrm{O}_{2}$. 3-Methylcatechol $(1 \mathrm{mM})$ was used as enzyme substrate without addition of $\mathrm{Fe}^{2+}$.

$N$-terminal amino acid sequence. A gas-phase amino acid sequence analysis according to the method of Edman was done on an Applied Biosystems 477 sequencer. The $\mathrm{N}$-terminal sequence obtained by this method, however, was not suitable for the synthesis of an oligonucleotide. Therefore, partial amino acid sequencing was carried out, using cyanogen bromide.

Chromatographic separation of $\mathrm{C} 23 \mathrm{OI}$ and $\mathrm{C} 23 \mathrm{OII}$ from $\mathrm{E}$. coli clones. Crude extracts from E. coli containing cloned $\mathrm{C} 230$ genes were prepared as described above. After an ammonium sulphate precipitation ( $30 \%$ saturation) and dialysis of the supernatant against buffer $\mathrm{A}$ (containing $1 \mathrm{~mm}-\mathrm{Fe}^{2+}$ ) overnight, aliquots of the protein samples were loaded onto an anion-exchange column (MonoQ, type HR 5/5). A linear $\mathrm{KCl}$ gradient $(0-1 \mathrm{M})$ was applied (flow rate $1 \mathrm{ml} \mathrm{min}^{-1} ; 0-6 \mathrm{ml}$ washing-off unbound protein; 6-21 ml, 0-1 M-KCl; 21-26 ml, $1 \mathrm{M}-$ $\mathrm{KCl}$ ). Active fractions were desalted, concentrated by ultrafiltration (PM10 membrane, Amicon), loaded onto a MonoQ column again, and 
eluted with a stepwise $\mathrm{KCl}$ gradient $(0-6 \mathrm{ml}, 0 \mathrm{M}-\mathrm{KCl} ; 6-12 \mathrm{ml}, 0-$ $0.4 \mathrm{M}-\mathrm{KCl} ; 16-21 \mathrm{ml} \mathrm{0.4-1} \mathrm{M-KCl)}$. Substrate specificity of the enzymes was determined with various catechols including 2,3-dihydroxyphenylpropionic acid and 2,3-dihydroxycinnamic acid. The reaction mixtures contained a suitable amount of protein and the corresponding substrate $(1.5 \mathrm{~mm})$ in a final volume of $1 \mathrm{ml}$. For determination of $\mathrm{C} 23 \mathrm{OI}$ activity the mixture was supplemented with $0.2 \mathrm{mM}-\mathrm{Fe}^{2+}$ and preincubated at $25^{\circ} \mathrm{C}$ for $1 \mathrm{~min}$.

DNA isolation. For analytical purposes plasmid DNA from $R$. rhodochrous was isolated as described by Anderson \& McKay (1983), with the following modifications. The incubation time of the cells with lysozyme $\left(10 \mathrm{mg} \mathrm{ml}^{-1}\right)$ was extended to $120 \mathrm{~min}$. Complete cell lysis was achieved after addition of SDS $(20 \%, w / v)$ and incubation for $30 \mathrm{~min}$ at $55^{\circ} \mathrm{C}$. Rapid preparations of plasmid DNA of E. coli clones was done according to Holmes \& Quigley (1981).

For preparative isolation of plasmid DNA from $R$. rhodochrous the cell pellet from a $50 \mathrm{ml}$ bacterial culture was resuspended in $7.6 \mathrm{ml}$ buffered sucrose $(6.7 \%, \mathrm{w} / \mathrm{v}$, sucrose, in $50 \mathrm{~mm}$-Tris $/ \mathrm{HCl}, 1 \mathrm{~mm}$ EDTA, pH 8.0). After addition of $2.0 \mathrm{ml}$ lysozyme $\left[40 \mathrm{mg} \mathrm{ml}^{-1}\right.$ in TE buffer (10 mM-Tris/HCl, $1 \mathrm{~mm}$-EDTA, $\mathrm{pH} 8.0)$ ] the cell suspension was incubated at $37^{\circ} \mathrm{C}$ for $15 \mathrm{~min}$. Then $970 \mu \mathrm{l} 250 \mathrm{~mm}$-EDTA, $50 \mathrm{~mm}-$ Tris $/ \mathrm{HCl}, \mathrm{pH} 8.0$, was added and incubation was continued for another $105 \mathrm{~min}$. Cells were lysed by addition of $600 \mu \mathrm{l}$ SDS $(20 \% \mathrm{w} / \mathrm{v}$ in $50 \mathrm{~mm}-$ Tris/ $\mathrm{HCl}, 20 \mathrm{~mm}$-EDTA, pH 8.0 ) and incubating at $55^{\circ} \mathrm{C}$ for $30 \mathrm{~min}$. The lysate was sheared by vigorous vortexing for $30 \mathrm{~s}$. Then alkaline denaturation was achieved by addition of $560 \mu$ f freshly prepared $3 \mathrm{M}$ $\mathrm{NaOH}$ followed by gentle mixing for $10 \mathrm{~min}$. The $\mathrm{pH}$ was decreased by adding $1 \mathrm{ml} 2.0 \mathrm{M}$-Tris $/ \mathrm{HCl}, \mathrm{pH} 7.0$, followed by gentle mixing for $5 \mathrm{~min}$. After addition of $2.1 \mathrm{ml}$ of $\operatorname{SDS}(20 \%, \mathrm{w} / \mathrm{v}$ in TE buffer $), 4.2 \mathrm{ml}$ of ice-cold $5.0 \mathrm{M}-\mathrm{NaCl}$ was added and the tubes were incubated at $4{ }^{\circ} \mathrm{C}$ for several hours or overnight. The precipitate was collected by centrifugation $\left(4^{\circ} \mathrm{C}, 48000 \mathrm{~g}, 90 \mathrm{~min}\right)$ and the clear supernatant containing the DNA was carefully removed. The DNA was precipitated by addition of 1 vol. cold propan-2-ol followed by incubation at $-20^{\circ} \mathrm{C}$ for $30 \mathrm{~min}$. After centrifugation $\left(4^{\circ} \mathrm{C}, 10000 \mathrm{~g}, 20 \mathrm{~min}\right)$ the precipitate was dissolved in $1.5 \mathrm{ml}$ TE buffer.

Vector DNA from $E$. coli was isolated by the method of Kieser (1984). Large-scale isolation of plasmid DNA from $E$. coli clones was performed by a brij lysis as described by Clewell \& Helinski (1969). All preparative plasmid DNA isolates were further purified by ultracentrifugation on caesium chloride gradients. Total DNA was prepared according to the method of Hopwood et al. (1985).

Recovery of DNA from agarose gels. Restriction fragments were recovered by the freeze-squeeze method described by Trautz \& Renz (1983).

Nucleic acid hybridization. A mixed oligonucleotide (5'$>$ GCYTGXTTXAAXAANGTGTC $<-3^{\prime} ; \quad \mathrm{Y}=\mathrm{T} / \mathrm{C}, \mathrm{X}=\mathrm{A} / \mathrm{G}$, $\mathrm{N}=\mathrm{A} / \mathrm{G} / \mathrm{C} / \mathrm{T}$ ) was synthesized by the $\beta$-cyanoethylphosphoamidite method on an Applied Biosystems $380 \mathrm{~A}$ instrument using the protocol provided by the manufacturer. This oligonucleotide was selected according to the partial amino acid sequence ${ }^{130} \mathrm{Asp}$-Thr-Phe-PheAsn-Glu-Ala ${ }^{136}$ ' of a cyanogen bromide peptide of $\mathrm{C} 23 \mathrm{OI}$ obtained by gas-phase amino acid sequence analysis. The oligonucleotide was labelled with $\left[\gamma^{-32}\right.$ P]ATP by using T4 polynucleotide kinase and hybridized with electrophoretically fractionated DNA transferred to nylon membrane filters (Southern, 1975). Hybridizations were carried out at room temperature overnight. Membranes were washed twice in $6 \times \mathrm{SSC}$ buffer $(20 \times \mathrm{SSC}$ is $3.0 \mathrm{M}-\mathrm{NaCl}, 0.3 \mathrm{M}$-sodium citrate, $\mathrm{pH} 7 \cdot 0)$ at room temperature followed by washes at $45^{\circ} \mathrm{C}$ and $50{ }^{\circ} \mathrm{C}$. The membranes were exposed to X-ray film at $-70^{\circ} \mathrm{C}$ for $12-48 \mathrm{~h}$.

Cloning experiments. The Rhodococcus-E. coli shuttle vector pMVS301 was used (Vogt Singer \& Finnerty, 1988) and plasmid DNA $(10 \mu \mathrm{g})$ from $R$. rhodochrous strains CTM and CTM2 was digested with
$B g l \mathrm{II}$ and size-fractionated by agarose gel electrophoresis. The desired restriction fragments were ligated to the vector pMVS301 after extraction from the agarose gel. pMVS301 $(2 \mu \mathrm{g})$ was digested with $B g / I I$ and treated with calf intestinal alkaline phosphatase. Ligation was carried out with $2 \mu \mathrm{g}$ plasmid DNA, $0.5 \mu \mathrm{g}$ vector DNA and 1 Unit of T4-DNA ligase. Competent cells of E. coli DH1 and E. coli TG2 were prepared according to Mandel \& Higa (1970). For subcloning in E. coli TG2 the Streptomyces-E. coli shuttle vector pJOE875 and the vector pUC18 were used.

\section{Results}

\section{Properties of C23OI}

C23OI purified (Table 2) from $R$. rhodochrous strain CTM showed a single band on SDS-PAGE, corresponding to a subunit $M_{\mathrm{r}}$ of $39000 \pm 2000$. The $M_{\mathrm{r}}$ of the native enzyme, determined by gel filtration, was $156000 \pm 3600$, suggesting that the native enzyme is a tetramer of four identical subunits. The isoelectric point of the enzyme was pH 4.4. The addition of acetone, as described for the stabilization of other metapyrocatechases (Nozaki, 1979), did not affect the stability of C23OI. The pH optimum of the enzyme was 8.0-8.5. Enzyme activity was highest between 50 and $65^{\circ} \mathrm{C}$. This high temperature is indicative of the heat stability of the enzyme which was still active after incubation at $80^{\circ} \mathrm{C}$ for $5 \mathrm{~min}$.

Microbial meta-cleavage enzymes usually contain ferrous iron (Nozaki, 1979). Therefore the effect of complexing agents, reducing and oxidizing agents and different metal ions on enzyme activity was tested. Complexing agents like 2,2'-bipyridyl and 1,10-phenanthroline inhibited $\mathrm{C} 23 \mathrm{OI}$ activity. $\mathrm{Hg}^{2+}(0.01 \mathrm{mM})$ and $3 \mathrm{mM}-\mathrm{Fe}^{3+}$ totally inhibited enzyme activity; $0.2 \mathrm{~mm}-$ $\mathrm{Fe}^{3+}$ caused $35 \%$ inhibition, $1 \mathrm{mM}-\mathrm{Ag}^{+} 53 \%, 0 \cdot 1 \mathrm{mM}-$ $\mathrm{Cu}^{2+} 43 \%$ and $0 \cdot 1 \mathrm{~mm}-\mathrm{Co}^{2+} 32 \%$. The enzyme was activated by ascorbate $(0.1 \mathrm{mM}$ for $50 \%)$ and by $\mathrm{Fe}^{2+}$ (1 $\mathrm{mM}$ for $94 \%$ ).

Analysis of the iron content revealed that $0.13 \mathrm{nmol}$ of the native enzyme contained $0.510 \mathrm{nmol}$ iron. On the basis of an $M_{\mathrm{r}}$ of 156000 and four identical subunits these data imply $0.98 \mathrm{~mol}$ of iron per subunit. Thus we conclude that one atom of $\mathrm{Fe}$ is bound per subunit of C23OI.

The $\mathrm{N}$-terminal amino acid sequence of $\mathrm{C} 23 \mathrm{OI}$ from $R$. rhodochrous strain CTM was found to be ${ }^{1}$ Glu-Ala-IleThr-Ser-Asp-Ser-Asn-Ile-Val-Glu-Val-Ser-Val-Pro ${ }^{15}$. Comparison with the published sequence of 3-methylcatechol 2,3-dioxygenase from Pseudomonas putida strain UCC2 (Wallis \& Chapman, 1990) showed that only the valine residues at position 12 was identical in these two meta-cleavage enzymes. 

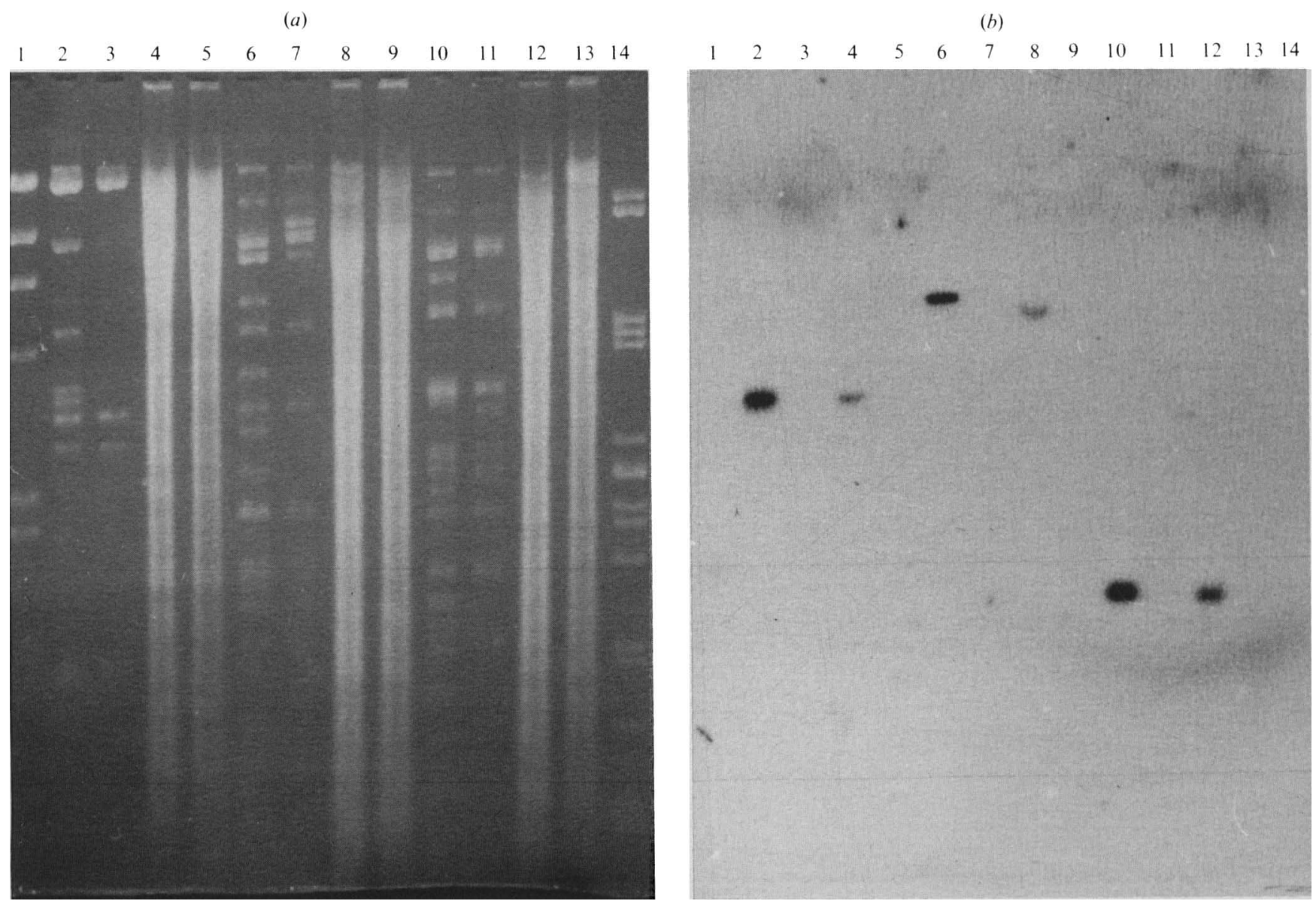

Fig. 1. (a) Agarose gel electrophoresis of BglII (lanes 2-5), Pst I (lanes 6-9) and BamHI (lanes 10-13) restriction enzyme digests of total plasmid DNA and total DNA from $R$. rhodochrous strains CTM and CTM2. Lane 1, $\lambda /$ HindIII size standards; lane 14, $\lambda / P$ st I size standards. Lanes 2, 6 and 10 show the plasmid DNA of strain CTM and lanes 3, 7 and 11 the plasmid DNA of strain CTM2. Lanes 4, 8 and 12 show total DNA from strain CTM, and lanes 5, 9 and 13 total DNA from CTM2. (b) Autoradiogram of a Southern blot hybridization of the DNA shown in (a) with ${ }^{32} \mathrm{P}$-labelled oligonucleotide derived from $\mathrm{C} 23 \mathrm{OI}$.

Table 2. Purification of C23O from R. rhodochrous CTM

\begin{tabular}{lccccc}
\hline \hline Fraction & Vol. (ml) & Protein (mg) & $\begin{array}{c}\text { Total } \\
\text { activity (mU) }\end{array}$ & $\begin{array}{c}\text { Specific activity } \\
\text { [mU (mg protein) })^{-1} \text { ] }\end{array}$ & $\begin{array}{c}\text { Purification } \\
\text { (-fold) }\end{array}$ \\
\hline Crude extract* & 89 & 712 & 1780 & $2 \cdot 5$ & $1 \cdot 0$ \\
DEAE-52 & 100 & 305 & 1000 & $3 \cdot 3$ & $1 \cdot 32$ \\
Superose-12 & 18 & $0 \cdot 72$ & 515 & 720 & 286 \\
Phenyl-Superose & 12 & 0.058 & 97 & 1690 & 676 \\
\hline \hline
\end{tabular}

* Prepared from $80 \mathrm{~g}$ cells (wet wt).

\section{Cloning of C23OI genes}

$R$. rhodochrous strain CTM harbours two plasmids of about $111 \mathrm{~kb}$ (pTC1) and $20.5 \mathrm{~kb}$ (pTC2). We probed plasmid DNA and total DNA of strain CTM with a mixed oligonucleotide synthesized on the basis of the amino acid sequence of a peptide with seven amino acids from the purified C23OI of $R$. rhodochrous strain CTM (see Methods). The probe hybridized strongly (Fig. 1) with a $3.5 \mathrm{~kb} \mathrm{BglII}$ fragment, a $5.7 \mathrm{~kb} P$ st I fragment and a $1.45 \mathrm{~kb}$ BamHI fragment of plasmid DNA from strain CTM. No hybridization was observed with plasmid and total DNA of strain CTM2.

Cloning the hybridizing $3.5 \mathrm{~kb} \mathrm{BglII}$ fragment in the vector pMVS301 with subsequent selection of transformants for $\mathrm{C} 23 \mathrm{O}$ activity by the catechol spray test yielded 27 positive clones. Analysis of the recombinant 


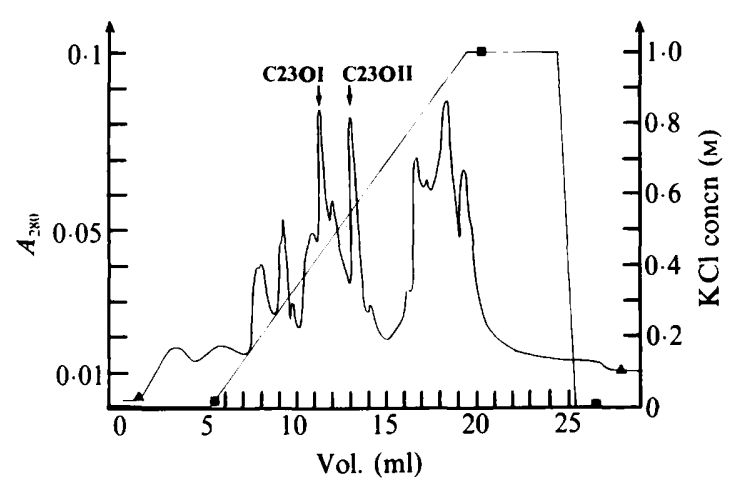

Fig. 2. Crude cell extract from $E$. coli DH1(pAS1360) eluted from a MonoQ ion-exchange column with a linear gradient of $0-1.0 \mathrm{M} \mathrm{KCl}$. The fractions in which cloned $\mathrm{C} 23 \mathrm{OI}$ and $\mathrm{C} 23 \mathrm{OII}$ eluted are marked by arrows. $\Delta$, Absorption of the fractions at $280 \mathrm{~nm} ; \square$, molarity of salt gradient.

Table 3. Substrate specificity of C23OII compared with $C 23 O I$ purified from $R$. rhodochrous CTM

The activity of $\mathrm{C} 23 \mathrm{OI}$ was measured after pre-incubating of the sample with $\mathrm{Fe}^{2+}$ for $1 \mathrm{~min} ; 100 \%$ activity $\equiv 4.7 \mathrm{mU}$ (mg protein $)^{-1}$. The activity of $\mathrm{C} 23 \mathrm{OII}$ was determined without addition of $\mathrm{Fe}^{2+} ; 100 \%$ activity $\equiv 1.0 \mathrm{mU}$ (mg protein) $)^{-1}$.

\begin{tabular}{lcc}
\hline & \multicolumn{2}{c}{ Relative activity (\%) } \\
\cline { 2 - 3 } Substrate & C23OI & C23OII \\
\hline Catechol & 100 & 100 \\
3-Methylcatechol & 360 & 63 \\
4-Methylcatechol & 165 & 45 \\
5-Chloro-3-methylcatechol & 144 & $10 \cdot 5$ \\
3-Chlorocatechol & 0 & 0 \\
4-Chlorocatechol & 51 & 31 \\
2,3-Dihydroxybenzoate & 0 & $9 \cdot 5$ \\
3,4-Dihydroxybenzoate & 0 & 3 \\
3,4-Dihydroxybenzoateethylester & 0 & 15 \\
3,4-Dihydroxybenzoatemethylester & 0 & 0 \\
2,3-Dihydroxyphenylpropionic acid & 0 & 8 \\
2,3-Dihydroxycinnamic acid & 0 & 33 \\
2,3-Dihydroxybiphenyl & 0 & 29 \\
3,4-Dihydroxybiphenyl & 0 & 0 \\
\hline \hline
\end{tabular}

plasmid DNA in these clones showed that the $3.5 \mathrm{~kb}$ $B g l \mathrm{II}$ fragment inserted in the vector pMVS301 randomly with respect to orientations as determined by digestion of the recombinant plasmids (pAS1360/pAS 1361) with HindIII. All clones showed constitutive expression of $\mathrm{C} 23 \mathrm{O}$. These findings suggested that no regulatory genes were present on the cloned $B g l I I$ fragment. Insertion of the $1.45 \mathrm{~kb} B a m H I$ fragment into the vector pUC18 did not yield clones with $\mathrm{C} 23 \mathrm{O}$ activity.

\section{Characterization of the gene products from cloned DNA.}

We partially purified the $\mathrm{C} 23 \mathrm{O}$ from recombinant $E$. coli cells harbouring pAS1360. Chromatography of the crude extract through an anion-exchange column (MonoQ) yielded two distinct protein peaks with $\mathrm{C} 23 \mathrm{O}$ activity when tested with 3-methylcatechol as substrate (see Fig. 2). Crude extracts from cells of $E$. coli strain DH1 carrying no recombinant plasmid, when separated on a MonoQ column, showed no protein peaks with C23O activity. Partial purification and characterization of the two proteins indicated that one protein was identical with $\mathrm{C} 23 \mathrm{OI}$ from $R$. rhodochrous CTM with respect to the $M_{\mathrm{r}}$ values of the native enzyme and its subunits, the substrate range and activation by $\mathrm{Fe}^{2+}$. The second protein represented an additional meta-cleaving enzyme, designated C23OII. The $M_{\mathrm{r}}$ of native $\mathrm{C} 23 \mathrm{OII}$ was found by gel-filtration to be $158000 \pm 3400$. Under denaturating conditions, a single protein band of $M_{\mathrm{r}} 40000 \pm 2000$ was demonstrated, indicating four identical subunits. The activity of purified C23OII decreased when preincubated with $\mathrm{Fe}^{2+}$ for $1 \mathrm{~min}$. This was in contrast to C23OI which was activated by such treatment. Comparison of the substrate specificity of the two enzymes from recombinant $E$. coli yielded the following results. The enzyme which was identical with $\mathrm{C} 23 \mathrm{OI}$ from $R$. rhodochrous strain CTM converted 3-methylcatechol much better than non-substituted catechol. C23OII, however, preferentially cleaved catechol. This enzyme accepted additional substrates like protocatechuic acid which was cleaved at the 2,3-position and 2,3-dihydroxybiphenyl which was cleaved at the 1,2-position. Neither compound was converted by $\mathrm{C} 23 \mathrm{OI}$ (Table 3). By exploiting this different substrate specificity of the two catechol dioxygenases, we were able to detect both active protein peaks in extracts from wild-type $R$. rhodochrous strain CTM by using 3-methylcatechol and 2,3-dihydroxybiphenyl as discerning substrates (data not shown).

\section{Subcloning}

In order to locate the structural genes for $\mathrm{C} 23 \mathrm{OI}$ and C23OII more precisely, the $3.5 \mathrm{~kb} \mathrm{BglII}$ insert of plasmid pAS1360 was mapped and subcloning experiments were done as shown in Fig. 3. Insertion of the $1.2 \mathrm{~kb} \mathrm{BglII-}$ SmaI fragment into pUC18 and pUC19 yielded no positive clones. Probing the clones with the oligonucleotide gave a strong signal with the inserted fragment. However, the $1.2 \mathrm{~kb}$ insert had suffered a deletion within the HindIII restriction site as determined by restriction enzyme analysis. The protein peak of $\mathrm{C} 23 \mathrm{OI}$ could be detected in the elution profile of crude extract from the MonoQ column. Obviously, this deletion led to the expression of inactive enzyme.

\section{Expression of C23OI and C23OII}

Results (Table 4) of experiments on $R$. rhodochrous extracts showed that both enzymes were induced during 

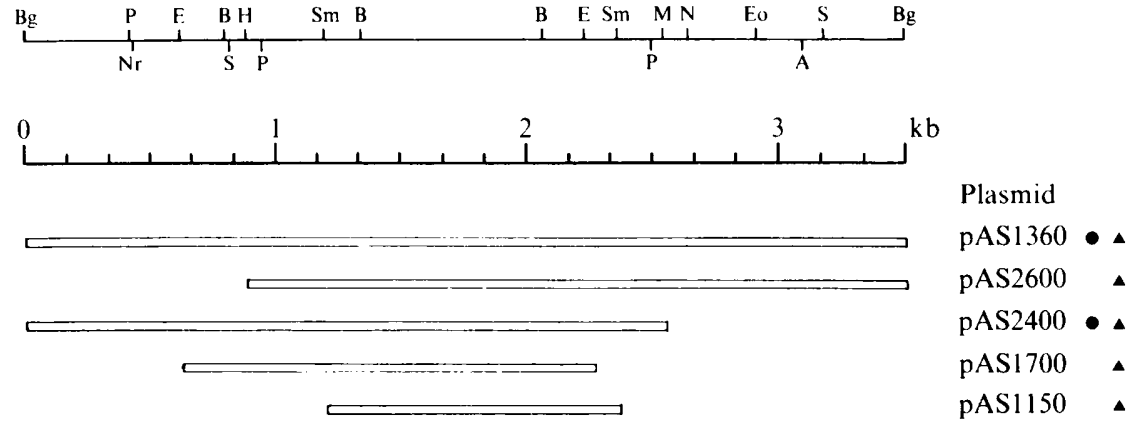

Fig. 3. Restriction map of the $3.5 \mathrm{~kb}$ Bg/II fragment from plasmid pTCl cloned in pMVS301 and its derivative subclones. The phenotype of the clones harbouring the corresponding plasmid is marked as follows: $\mathrm{C}_{23 \mathrm{OI}}^{+}(\boldsymbol{\theta}) ; \mathrm{C}^{230 I I}{ }^{+}(\boldsymbol{A})$. The abbreviations for the restriction enzymes are as follows: A, ApaI; B, BamHI; Bg, BglII; E, EcoRI; Eo, EcoRV; H, HindIII; M, MluI; N,NaeI; Nr, NruI; P, PvuI; S, Sst I; Sm, SmaI.

Table 4. Specific activities of $C 23 O I$ and $C 23 O I I$ in crude extracts of different E. coli clones and in $R$. rhodochrous CTM

\begin{tabular}{|c|c|c|c|c|c|c|}
\hline \multirow[b]{3}{*}{ Strain } & \multirow{3}{*}{$\begin{array}{l}\text { Substrate } \\
\text { Phenotype }\end{array}$} & \multicolumn{4}{|c|}{ Specific activity [mU (mg protein $\left.)^{-1}\right]$} & \multirow[b]{3}{*}{ Induction } \\
\hline & & \multicolumn{2}{|c|}{.3-Methylcatechol } & \multicolumn{2}{|c|}{ 2,3-Dihydroxybiphenyl } & \\
\hline & & $-\mathrm{Fe}^{2+}$ & $+\mathrm{Fe}^{2+}$ & $-\mathrm{Fe}^{2+}$ & $+\mathrm{Fe}^{2+}$ & \\
\hline R. rhodochrous $\mathrm{CTM}$ & $\mathrm{C}_{23 \mathrm{OI}}+\mathrm{C}_{23 \mathrm{OII}}{ }^{+}$ & 0 & 0 & 0 & 0 & None \\
\hline R. rhodochrous CTM & 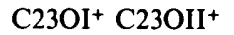 & 3.6 & $8 \cdot 6$ & 0.8 & $<0 \cdot 1$ & $o$-Toluidine \\
\hline$R$. rhodochrous CTM & 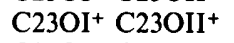 & 0.75 & $2 \cdot 4$ & $0 \cdot 2$ & $<0 \cdot 1$ & Biphenyl \\
\hline E. coli (pAS1360) & $\mathrm{C}_{23 \mathrm{OI}^{+}} \mathrm{C}_{23} 3 \mathrm{OII}^{+}$ & $8 \cdot 8$ & $11 \cdot 4$ & 8.2 & $7 \cdot 2$ & None \\
\hline E. coli (pAS1700) & $\mathrm{C}^{2} 3 \mathrm{OI}^{-} \mathrm{C}^{23 \mathrm{OII}^{+}}$ & $72 \cdot 0$ & $51 \cdot 6$ & $43 \cdot 6$ & $15 \cdot 3$ & None \\
\hline E. coli (pAS1150) & ${\mathrm{C} 23 \mathrm{OI}^{-}}^{-\mathrm{C}_{23} \mathrm{OII}^{+}}$ & $29 \cdot 7$ & $25 \cdot 6$ & $12 \cdot 9$ & $5 \cdot 1$ & None \\
\hline
\end{tabular}

cultivation in the presence of 2-methylaniline or biphenyl. As C23OII also converted 3-methylcatechol (see Table 3), the data for enzyme activities with 3methylcatechol as substrate are the sum of $\mathrm{C} 23 \mathrm{OI}$ and C23OII activities in $R$. rhodochrous strain CTM and also in $E$. coli clones harbouring the genes for both enzymes (pAS1360). The enzyme activities measured with dihydroxybiphenyl as substrate can be attributed exclusively to $\mathrm{C} 23 \mathrm{OII}$ activity. In E. coli clones the activities of metacleaving enzymes were significantly higher than in $R$. rhodochrous due to the presence of a strong promotor in these clones.

\section{Discussion}

Our studies on the differences between wild-type $R$. rhodochrous strain CTM and the spontaneous mutant strain CTM2 at the enzymic and genetic level confirmed that the mutant strain CTM2 has lost a $3.5 \mathrm{~kb}$ fragment of plasmid pTC1 which carries the genes for $\mathrm{C} 23 \mathrm{OI}$ and
$\mathrm{C} 23 \mathrm{OII}$, and therefore exhibits the $\mathrm{C}^{2} 3 \mathrm{O}^{-}$phenotype. Our studies included cloning, expression and investigating some properties of two isofunctional catechol 2,3-dioxygenases in $R$. rhodochrous CTM. One of them (C23OI) exhibits a high affinity towards methylcatechols.

Two kinds of meta-cleavage enzymes have been described which are able to convert methylcatechols. One type prefers unsubstituted catechol as substrate (Murray et al., 1972; Latorre et al., 1984) and the second shows a preference for methylcatechols (Bayly et al., 1977; Wallis \& Chapman, 1990).

Up until now, only one meta-cleavage enzyme from a Rhodococcus species has been purified (Rast et al., 1980). It belongs to the second enzyme-type, like the $\mathrm{C} 23 \mathrm{OI}$ of $R$. rhodochrous strain CTM. Both enzymes, however, differ widely in most of their properties such as substrate specificity, the number of subunits, activation by $\mathrm{Fe}^{2+}$ and sensitivity towards metal ions (Rast et al., 1980). The main difference between $R$. rhodochrous strain CTM, $R$. rubrus and other rhodococci that are known to have a 
$\mathrm{C} 23 \mathrm{O}$ is the presence of two meta-cleavage enzymes in $R$. rhodochrous strain CTM.

C23OI converts 3-methylcatechol at higher rates than unsubstituted catechol. Recently, a meta-cleavage enzyme of the same substrate specificity type from the methylaniline-degrading Pseudomonas putida strain UCC2 (McClure \& Venables, 1986, 1987), was described by Wallis \& Chapman (1990). Although the first 15 amino acid residues of the $\mathrm{N}$-termini of the enzymes from $P$. putida strain UCC2 and $R$. rhodochrous strain CTM showed no homology, both enzymes are comparable regarding their native $M_{\mathrm{r}}$ values, number of subunits, optimal $\mathrm{pH}$ and the activating effect of $\mathrm{Fe}^{2+}$. Treatment of both enzymes with oxidants and $\mathrm{H}_{2} \mathrm{O}_{2}$ resulted in irreversible loss of enzyme activity. The restriction endonuclease maps of the $\mathrm{C} 23 \mathrm{O}$ gene from $P$. putida strain UCC2 (Saint et al., 1990) and the C23OI gene from $R$. rhodochrous strain CTM, however, showed no similarity.

C23OII from $R$. rhodochrous strain CTM is very similar to C23OI with respect to the $M_{\mathrm{r}}$ of the native enzyme and the number and size of the subunits, but C23OII shows less pronounced substrate specificity. C23OII preferentially converts non-substituted catechol and additionally catechols derived from phenyl carboxylic acids and 2,3-dihydroxybiphenyl. C23OII is completely different in size and number of subunits from previously described 2,3-dihydroxybiphenyl dioxygenases, which either had more than four subunits (Furukawa \& Arimura, 1987) or consisted of nonidentical subunits (Selivonov et al., 1988). C23OII, like all other dihydroxybiphenyl dioxygenases, accepts 2,3dihydroxybiphenyl but not 3,4-dihydroxybiphenyl as a substrate. A further characteristic of C23OII of $R$. rhodochrous strain CTM is the cleavage of protocatechuate at the 2,3-position and not at the 4,5-position, which is the case for most other meta-cleavage enzymes. Up until now, cleavage at the 2,3-position has been observed only for the protocatechuate dioxygenase from Bacillus spp. (Crawford, 1975; Crawford et al., 1979), and this was believed to be a specific taxonomic feature.

The existence of more than one meta-pyrocatechase in xenobiotic-degrading micro-organisms is not uncommon. In various biphenyl-degrading bacteria as well as in Pseudomonas strains harbouring TOL plasmids (Chatfield \& Williams, 1986; Keil et al., 1985) two metapyrocatechases have been observed (Selivonov et al., 1988; Furukawa et al., 1983; Furukawa \& Arimura, 1987). Pseudomonas MT 15 harbouring plasmid pWW15 has two non homologous C23O enzymes (Keil et al., 1985) which convert catechol and 3-methylcatechol to a similar extent, like the dioxygenases of $R$. rhodochrous strain CTM. In contrast to P. putida MT15, where the two dioxygenase genes are located at different positions
(Keil et al., 1985), in $R$. rhodochrous CTM the genes for both dioxygenases are clustered on a $2 \cdot 4 \mathrm{~kb} B g l \mathrm{II}-M l u \mathrm{I}$ restriction fragment of plasmid pTCl.

This work was supported by the Bundesministerium für Forschung und Technologie and the Fonds der Chemischen Industrie. We thank Dr J. Eberspächer for critical reading of the manuscript.

\section{References}

ANDERSON, D. G. \& MCKAY, L. (1983). Simple and rapid method for isolating large plasmid DNA from lactic streptococci. Applied and Environmental Microbiology 46, 549-552.

Bayly, R. C., Wigmore, G. J. \& McKenzie, D. J. (1977). Regulation of the enzymes of the meta-cleavage pathway of Pseudomonas putida. the regulon is composed of two operons. Journal of General Microbiology 100, 71-79.

Britton, H. T. S. \& Robinson, R. A. (1931). Universal buffer solutions and the dissociation constant of Veronal. Journal of the Chemical Society 1456.

Catelani, D. \& Colombi, A. (1974). Metabolism of biphenyl. Biochemical Journal 143, 431-434.

Chatfield, L. K. \& Williams, P. A. (1986). Naturally occurring TOL plasmids in Pseudomonas strains carry either two homologous or two nonhomologous catechol 2,3-oxygenase genes. Journal of Bacteriology 168, 878-885.

Clewell, D. B. \& HelinsKi, D. R. (1969). Supercoiled circular DNAprotein complex in E. coli: purification and induced conversion to an open circular DNA form. Proceedings of the National Academy of Sciences of the United States of America 62, 1159-1166.

CRAWFORD, R. L. (1975). Novel pathway for the degradation of protocatechuic acid in Bacillus species. Journal of Bacteriology 121, 531-536.

Crawford, R. L., Bromley, J. W. \& Perkins-Olson, P. E. (1979). Catabolism of protocatechuate by Bacillus macerans. Applied and Environmental Microbiology 37, 614-618.

Fuchs, K., Schreiner, A. \& Lingens, F. (1990). Degradation of 2methylaniline and chlorinated isomers of 2-methylaniline by Rhodococcus rhodochrous strain CTM. Journal of General Microbiology 137, 2033-2039.

Furukawa, K., Simon, J. R. \& Chakrabarty, A. M. (1983). Common induction and regulation of biphenyl, xylene/toluene and salicylate catabolism in Pseudomonas paucimobilis. Journal of Bacteriology 154, 1356-1362.

Furukawa, K. \& Arimura, N. (1987). Purification and properties of 2,3-dihydroxybiphenyl dioxygenase from polychlorinated biphenyl degrading Pseudomonas pseudoalcaligenes and Pseudomonas aeruginosa carrying the cloned bphC gene. Journal of Bacteriology 169, 924-927.

Holmes, D. S. \& Quigley, M. (1981). A rapid boiling method for the preparation of bacterial plasmids. Analytical Biochemistry 114, 193197.

Hopwood, D. A., Bibb, M. J., Chater, K. F., Kieser, T., Bruton, C. J., Kieser, H. M., Lydiate, D. J., Smith, C. P., Ward, J. M. \& SCHREMPF, H. (1985). Genetic manipulation of Streptomyces: a Laboratory Manual. Norwich: John Innes.

KeIL, H., Lebens, M. R. \& Williams, P. A. (1985). TOL plasmid pWW15 contains two non-homologous independently regulated catechol 2,3-oxygenase genes. Journal of Bacteriology 163, 248-255.

KIESER, T. (1984). Factors affecting the isolation of ccc DNA from Streptomyces lividans and Escherichia coli. Plasmid 12, 19-36.

LAEMmLI, U. K. (1970). Cleavage of structural proteins during the assembly of the head of bacteriophage T4. Nature, London 227, 680685.

Latorre, J., Reinecke, W. \& Knackmuss, H.-J. (1984). Microbial metabolism of chloroanilines: enhanced evolution by natural genetic exchange. Archives of Microbiology 140, 159-165.

MANDEL, M. \& HigA, A. (1970). Calcium dependent bacteriophage DNA infection. Journal of Molecular Biology 53, 159-162. 
Maniatis, T., Fritsch, E. F. \& Sambrooxe, J. (1989). Molecular Cloning: a Laboratory Manual. Cold Spring Harbor, NY: Cold Spring Harbor Laboratory.

MCCluRe, N. C. \& Venables, W. A. (1986). Adaption of Pseudomonas putida $\mathrm{mt}-2$ to growth on aromatic amines. Journal of General Microbiology 132, 2209-2218.

MCClure, N. C. \& Venables, W. A. (1987). pTDN1, a catabolic plasmid involved in aromatic amine catabolism in Pseudomonas putida mt-2. Journal of General Microbiology 133, 2073-2077.

Murray, K., Duggleby, C. J., Sala-Trepat, J. M. \& Williams, P. A. (1972). The metabolism of benzoate and methylbenzoates via the meta-cleavage pathway by Pseudomonas arvilla mt-2. European Journal of Biochemistry 28, 301-310.

NozAKI, M. (1979). Oxygenases and dioxygenases. In Topics in Current Chemistry. Berlin: Springer Verlag.

Rast, H. G., ENGelhardt, G. \& Wallnöfer, P. R. (1980). 2,3cleavage of substituted catechols in Nocardia sp. DSM 43251 (Rhodococcus rubrus). Zentralblatt für Bakteriologie und Hygiene (Abteilung I, Originale C) 224-236.

Saint, C. P., McClure, N. C. \& Venables, W. A. (1990). Physical map of the aromatic amine and $m$-toluate catabolic plasmid pTDN 1 in Pseudomonas putida: location of a unique meta-cleavage pathway. Journal of General Microbiology 136, 615-625.

Schmitt, S., Müller, R., Wegst, W. \& Lingens, F. (1984). Chloridazon-catechol dioxygenases, a distinct group of metacleaving enzymes. Hoppe-Seyler's Zeitschrift für Physiologische Chemie 365, 143-150.
Selivonov, S. A., Starovoitov, I. I. \& Skryabin, G. K. (1988). Purification and properties of two enzymes of meta-cleavage of the aromatic ring, controlled by the plasmid of biphenyl biodegradation, pBS241, from the bacteria Pseudomonas putida. Biochemistry 53, 905911 (English translation of Biokhimiya).

SOUTHERN, E. M. (1975). Detection of specific sequences among DNA fragments separated by gel electrophoresis. Journal of Molecular Biology 98, 503-517.

Trautz, D. \& Renz, M. (1983). An optimal freeze-squeeze method for the recovery of DNA fragments from agarose gel. Analytical Biochemistry 132, 14-19.

Vieira, J. \& Messing, J. (1982). The pUC plasmids, an M13mp7derived system for insertion mutagenesis and sequencing with synthetic universal primers. Gene 19, 259-268.

VOGT Singer, M. E. \& FinNeRTY, W. R. (1988). Construction of an Escherichia coli-Rhodococcus shuttle vector and plasmid transformation in Rhodococcus spp. Journal of Bacteriology 170, 638-645.

Wallis, M. G. \& CHAPMAN, K. (1990). Isolation and partial characterization of an extradiol non-haem iron dioxygenase which preferentially cleaves 3-methylcatechol. Biochemical Journal 266, 605-609.

Worsey, M. J., Franklin, F. Ch. \& Williams, P. A. (1978). Regulation of the degradative pathway enzymes coded for by the TOL plasmid (pWWO) from Pseudomonas putida mt-2. Journal of Bacteriology 134, 757-764. 